OPEN ACCESS

Edited by:

Artur Mayerhofer,

Ludwig Maximilian University of

Munich, Germany

Reviewed by:

Qi Yu,

Peking Union Medical College Hospital (CAMS), China

Winnie Shum,

ShanghaiTech University, China

*Correspondence: Jens Vanselow vanselow@fbn-dummerstorf.de

Specialty section This article was submitted to Reproduction,

a section of the journal

Frontiers in Endocrinology

Received: 26 November 2019

Accepted: 11 February 2020

Published: 25 February 2020

Citation:

Sharma A, Baddela VS, Roettgen V,

Vernunft $A$, Viergutz $T$,

Dannenberger D, Hammon HM,

Schoen J and Vanselow J (2020)

Effects of Dietary Fatty Acids on

Bovine Oocyte Competence and

Granulosa Cells.

Front. Endocrinol. 11:87.

doi: 10.3389/fendo.2020.00087

\title{
Effects of Dietary Fatty Acids on Bovine Oocyte Competence and Granulosa Cells
}

\begin{abstract}
Arpna Sharma, Vijay Simha Baddela, Volker Roettgen, Andreas Vernunft, Torsten Viergutz, Dirk Dannenberger, Harald M. Hammon, Jennifer Schoen and Jens Vanselow*
\end{abstract}

Reproductive Biology Unit, Leibniz Institute for Farm Animal Biology (FBN), Dummerstorf, Germany

Here we assessed the effects of dietary essential fatty acids on the developmental competence of oocytes in cows and on the functionality of follicular granulosa cells (GC). Lactating German Holstein cows were supplemented from week 9 ante partum (ap) until week 8 post-partum (pp) in four dietary groups designed as (i) control (CTRL: coconut oil), (ii) essential fatty acid (EFA: linseed and safflower oil), (iii) conjugated linoleic acid (CLA: Lutalin ${ }^{\circledR}$ ), and (iv) EFA+CLA (mixture of linseed oil, safflower oil and Lutalin ${ }^{\circledR}$ ). EFA, CLA or EFA+CLA supplementation did not improve in vitro embryo production. However, higher proportions of $\alpha$-linolenic acid (ALA) and cis-9, trans-11 CLA were observed in the follicular fluid suggesting the exposure of $G C$ to relatively high levels of ALA and cis-9, trans-11 CLA. Consequently, we tested different concentrations of ALA and cis-9, trans-11 CLA in a bovine GC culture model for their effects on steroid production, marker gene expression and viability. Both fatty acids upregulated CD36 and downregulated the expression of FOXL2, while ALA significantly increased SOX 9 transcript levels. Both ALA and cis-9, trans-11 CLA reduced the CCND2 expression and cis-9, trans-11 CLA induced apoptosis. ALA and cis-9, trans-11 CLA significantly down-regulated the expression of STAR, CYP19A1, FSHR, LHCGR and decreased the $17 \beta$-Estradiol (E2) and progesterone (P4) production. In conclusion, dietary lipids did not improve in vitro embryo production, while ALA and cis-9, trans-11 CLA affected the morphology and functionality of GC. This could suggestively lead to compromised follicle development and ovarian cyclicity in dairy cows.

Keywords: alpha-linolenic acid, conjugated linoleic acid, estradiol, granulosa cells, gene expression

\section{INTRODUCTION}

Dietary supplements can improve the reproductive outcome in cows by increasing the energy intake thus reducing the extent of negative energy balance (NEB) experienced postpartum (1). Polyunsaturated fatty acids (PUFA) enriched diets in cattle are known to alleviate NEB during early lactation (2). PUFA at the cellular level maintain several functions such as membrane stability, regulation of transcription factors, cell proliferation and differentiation (3). Among PUFA, essential fatty acids such as linoleic acid (LA) and $\alpha$-linolenic acid (ALA) are not synthesized in cows, human and pigs and must be supplied through the diet (4). In vivo, the nutritional effects of PUFA are wellknown to affect the oocyte metabolism and early development in livestock species (5). The fatty acid (FA) profile of the follicular fluid (FF) is well-correlated to the type of dietary FA surrounding the 
oocytes as dietary fats can alter the FA composition in cumulus and granulosa cells (GC) thus influencing oocyte quality (6). Ewes fed with PUFA diets showed higher proportions of LA and docosahexaenoic acid (DHA) in FF and cumulus cells with lower proportions in oocytes (7). The size of dominant follicles is reported to increase in cows fed with PUFA diets as compared to cows fed with monounsaturated fatty acids (MUFA) (8). Increased follicle size is supposed to improve both oocyte quality and corpus luteum (CL) function in cows (9). Larger ovulatory follicles with lower rates of pregnancy losses were found in cows fed with flaxseed (9.8\%) compared to those fed with sunflower seed (27.3\%) (10). Among other dietary fats, conjugated linoleic acid (CLA) isomers (cis-9, trans-11 and trans10, cis-12) comprise a group of PUFA derived from LA during incomplete biohydrogenation by the ruminal flora in cattle and sheep (11). CLA increases the plasma concentration of insulinlike growth factor-1 (IGF-1) in cows, thus promoting conception rates (12). CLA supplements decrease the milk fat excretion during the early lactation period saving energy in order to combat the physiological NEB (13). As CLA at physiological concentrations has been found to affect nuclear maturation of cumulus oocyte complexes (COCs) and similarly, LA could also negatively affect both oocyte and embryo development due to altered glutathione peroxidase and superoxide dismutase mRNA expression (14). Negligible effects of ALA and LA diets on cleavage and embryo development from oocytes collected via ovum pick up (OPU) have been reported (15). Cows fed with omega-3 ( $\omega-3)$ enriched diet failed to enhance the ovulation even upon ovarian stimulation (16). Dietary effects of essential fatty acids particularly ALA and CLA or their mixture on oocyte developmental competence as well as their effects on GC functionality still remain to be elucidated in detail. Thus, the primary objective of the study was to determine the effect of essential fatty acids especially of ALA and CLA by abomasal supplementation in lactating cows to assess the effects on in vitro preimplantation embryo development. We also analyzed the FA compositions of FF in the different dietary groups and elucidated the effects of increased concentrations of ALA and cis-9, trans11CLA on the morphology, hormone production, viability, and gene expression of cultured bovine GC.

\section{MATERIALS AND METHODS}

\section{Animals and Dietary Supplementation}

Handling of animals and the experimental design were approved by the federal state of Mecklenburg Western-Pommerania, Germany (LALLF M-V TSD 7221.3-1-038/15). Forty German Holstein-Friesian cows at 18 th week of gestation in their 2 nd lactation were kept in a free-stall barn at the Leibniz Institute for Farm Animal Biology (FBN), Dummerstorf, Germany. Cows included in the study were surgically fitted with rumen fistulas and abomasal tubes to bypass rumen derived biohydrogenation of supplemented FA (17). The cows were studied in 5 blocks each consisting of 8 cows ( 2 cows per supplementation group and per block) from week 9 ante partum (ap) up to week 8 post-partum (pp) in their 3rd lactation. The ingredients and the composition of the diet, separately for lactation and dry-off diet are shown in Supplementary Table 1. FA composition of all four oil supplements is shown in Supplementary Table 2. Cows were supplemented daily from week 9 ap until week 8 pp either with $76 \mathrm{~g} / \mathrm{d}$ coconut oil (CTRL $n=9$ ), $78 \mathrm{~g} / \mathrm{d}$ linseed and $4 \mathrm{~g} / \mathrm{d}$ safflower oil (EFA $n=9$ ) providing a $\omega-6 / \omega-3$ FA ratio of $1: 3$, Lutalin ${ }^{\circledR}$ (CLA $n=10,10 \mathrm{~g} / \mathrm{d}$ of cis-9, trans-11, and cis-10, trans12 CLA isomer, respectively) or a mixture of linseed and safflower oil plus Lutalin ${ }^{\circledR}(\mathrm{EFA}+$ CLA $n=10)$. Following last dietary supplementation, cows in wk 9 pp were slaughtered for oocyte collection by the slicing method. In between, due to abortions in week 6 ap, 4 cows had to be removed from the study though two of these cows were replaced. Thus, altogether 38 cows were examined throughout the experimental duration.

\section{FA Analysis by Gas Chromatography}

FF from large follicles (10-24 mm) was aspirated from ovaries of the experimental cows after slaughter. Approximately 500 $\mu \mathrm{L}$ of $\mathrm{FF}$ was dropwise added to $8 \mathrm{~mL}$ chloroform/methanol $(2: 1, \mathrm{v} / \mathrm{v})$ at room temperature. The fatty acid C19:0 used as an internal standard. The procedure for sample preparation was performed as described earlier (18). The fatty acid analysis of the FF was executed using capillary gas chromatography with a CP-Sil 88 CB column $(100 \mathrm{~m} \times 0.25 \mathrm{~mm}$, Chrompack-Varian, Lake Forest, CA, USA) which was installed in a PerkinElmer gas chromatograph Autosys XL with a flame ionization detector (PerkinElmer Instruments, Shelton, CT, USA). The complete gas chromatography conditions were as described earlier (19). Hydrogen at a flow rate of $1 \mathrm{~mL} / \mathrm{min}$ was used as the carrier gas while the split ratio was 1:20 with the injector and detector set to 260 and $280^{\circ} \mathrm{C}$, respectively.

\section{In vitro Production (IVP) of Embryos}

The IVP protocol was executed using the IVF Bioscience media suite formulated for bovine embryo production according to the manufacturer's instructions (IVF Bioscience, Falmouth, United Kingdom, catalog \# 61002, 61004, 61003, 61010, 61001, and 62000) (20). Briefly, 6-10 COCs obtained from cows of different diet groups after slaughter were matured in BO-IVM media and incubated for $24 \mathrm{~h}\left(38.5^{\circ} \mathrm{C}, 6 \% \mathrm{CO}_{2}\right)$. For IVF, 2 $\times 10^{6}$ sperms $/ \mathrm{ml}$ from proven fertile Holstein Friesian bull were added to BO-IVF media containing matured oocytes and incubated for $18-22 \mathrm{~h}\left(38.8^{\circ} \mathrm{C}, 6 \% \mathrm{CO}_{2}, 21 \% \mathrm{O}_{2}\right)$. Putative zygotes were cultured in BO-IVC media and overlaid by BOOil and incubated at $38.8^{\circ} \mathrm{C}, 6 \% \mathrm{CO}_{2}, 6 \% \mathrm{O}_{2}, 88 \% \mathrm{~N}_{2}$. Embryo cleavage was examined $48 \mathrm{~h}$ post IVF and subsequent embryo development was evaluated on day 8 post IVF. To count total cell number (TCN), embryos were fixed in $4 \%(\mathrm{v} / \mathrm{v})$ paraformaldehyde (Sigma 252549) and stored at $4^{\circ} \mathrm{C}$ overnight. Embryos were mounted on glass slides and stained with Hoechst 33258 (Sigma B1155). Images were captured by confocal laser scanning microscope LSM 800 assembled with ZEN software (Carl Zeiss, Oberkochen, Germany).

\section{Primary GC Culture}

Primary GC culture and bovine serum albumin (BSA)-FA conjugate preparations were done as described earlier (21). For testing the effects of actual follicular concentration 
of ALA (Sigma-Aldrich,L2376) and cis-9, trans-11CLA (Sigma-Aldrich,16413) the media were replaced every $48 \mathrm{~h}$ with supplemented $\alpha$-MEM media containing different concentrations of ALA $(20,40$, and $80 \mu \mathrm{M})$ or cis-9, trans-11 CLA $(15,30$, and $60 \mu \mathrm{M})$ as BSA conjugates or non-conjugated BSA as vehicle control (Sigma-Aldrich A7030). All control wells received the same volume of BSA as the test groups with highest fatty acid concentration. The conditioned media collected on the 8th day of culture were stored at $-20^{\circ} \mathrm{C}$ for steroid hormone estimation, while the remaining cells were lysed for RNA isolation.

\section{Steroid Hormone Analysis}

Concentration of E2 and P4 of GC conditioned media were determined by competitive $3 \mathrm{H}$-radioimmunoassay (RIA) with rabbit-raised antibodies purified by affinity chromatography as performed earlier (22). Radioactivity was measured in a liquid scintillation counter (LSC) with an integrated RIA-calculation programme (TriCarb 2900 TR; PerkinElmer).

\section{Flow Cytometry}

On day 8 of GC culture, cells were thoroughly washed twice with phosphate buffered saline (PBS) and then trypsinized using $250 \mu \mathrm{l}$ TryplE solution (Thermo Fischer, USA) at $37^{\circ} \mathrm{C}$ for $20 \mathrm{~min}$. Post trypsinization, all detached cells were centrifuged and resuspended in $1 \mathrm{ml}$ MEM and analyzed for viability and apoptosis using an Annexin-V FITC/PI kit (Miltenyi biotec, Germany). Cells were centrifuged and pellets were re-suspended in $100 \mu \mathrm{l}$ of binding buffer to which $10 \mu \mathrm{l}$ of Annexin V reagent was added and kept for incubation in the dark for $15 \mathrm{~min}$. followed by washing and resuspension in $500 \mu \mathrm{l}$ binding buffer. Next, $5 \mu$ l of PI (Propidium iodide, $500 \mu \mathrm{g} / \mathrm{ml}$ ) was added to the cells with gently mixing just prior to flow cytometric analysis. The fluorescence signal was quantified from single cells (10,000 counts) by a flow cytometer (Gallios, Beckman-Coulter, Germany) and the data obtained was analyzed using the Kaluzasoftware (Beckman-Coulter, Germany).

\section{RNA Isolation, cDNA Synthesis, and Real Time-Quantitative PCR (RT-qPCR)}

RNA isolation was performed using the innuPREP RNA Mini Kit (Analytik Jena, Germany) according to the manufacturer's protocol and quantified with NanoDrop1000 Spectrophotometer (Thermo Scientific, Bonn, Germany). Later, cDNA was synthesized using the SensiFAST cDNASynthesis Kit (Bioline, Luckenwalde, Germany) from 200 ng RNA as done previously (23). The RT-qPCR was executed for gene expression analysis, using SensiFAST SYBR No-ROX (Bioline) with gene-specific primers (Supplementary Table 3) in a Light Cycler 96 instrument (Roche, Mannheim, Germany) (24).

\section{Statistical Analysis}

IVF data were analyzed by one-way ANOVA (Holm-Sidak method, all pair wise multiple comparison procedure). The mean proportions of follicular fatty acids in supplemented diet groups was compared by one way ANOVA (Holm-Sidak method) or ANOVA on ranks (Dunn's Method) for pairwise multiple comparisons. The RIA, RT-qPCR gene expression and flow cytometry data (at least three biological replicates) were analyzed by one-way repeated measure ANOVA (all pair wise multiple comparison or multiple comparison vs. control procedures with Holm-Sidak or Dunnett test where applicable) or ANOVA on ranks when normality test failed using SigmaPlot 11.0. Significant changes were recognized if $P<0.05$.

\section{RESULTS}

\section{FA Analysis of Dietary Lipid Supplements in Follicular Fluid}

The proportions of different FA were analyzed in the FF of all four dietary groups (Table 1). The percentage of ALA was significantly $(P<0.05)$ higher in the EFA and EFA + CLA diet groups with $10.19 \pm 2.36 \%$ and $12.56 \pm 2.02 \%$, respectively, as compared to the CTRL $(2.81 \pm 0.46 \%)$ and CLA diet groups $(2.44 \pm 0.45 \%)$. While cis-9, trans-11 CLA isomer was significantly higher $(P<0.05)$ in the CLA and EFA+CLA diet groups with $0.4 \pm 0.12 \%$ and $0.29 \pm 0.03 \%$, as compared to the CTRL and EFA diet groups $(0.15 \pm 0.15 \%$ and $0.07 \pm 0.03 \%)$. Further, due to higher proportions of ALA and cis-9, trans-11 CLA in FF, we speculate that GC are exposed to relatively high levels of ALA and cis-9, trans-11 CLA which might affect the functionality of GC residing within. Consequently, we tested different concentrations of both ALA and cis-9, trans-11 CLA in our GC culture model.

\section{In vitro Embryo Development}

A total number of 260 oocytes were recovered after slicing the ovaries obtained from cows of each diet group. We did not supplement the in vitro culture media with any FA for IVP. As for IVP we purely analyzed the developmental competence of obtained oocytes in vitro. The percentage of oocytes which underwent cleavage $48 \mathrm{~h}$ after fertilization and the blastocyst rates at the 8th day are presented in Table 2. The cleavage rates of oocytes recovered from the EFA and CLA diet groups tended to be higher $(51.7 \% \pm 9.3 \%$ and $53.3 \% \pm 5.1 \%)$ as compared to those of EFA + CLA $(36.2 \% \pm 10.6 \%)$ and of the CTRL $(34 \pm$ $8.1 \%)$, however without statistical significance. Similarly, the rate of blastocysts generated from the cleaved embryos in the CTRL $(23.5 \% \pm 11.7 \%)$ and in the EFA, CLA and EFA+CLA diet groups $(17.4 \% \pm 7.9 \%, 26.1 \pm 11.2 \%$, and $15.2 \% \pm 8.4 \%$, respectively) remained statistically indifferent. Blastocysts generated on day 8 post IVF from each diet groups were stained with Hoechst 33258 to assess the TCN (Figure 1). The TCN count in EFA, CLA and EFA + CLA were $92.1 \pm 10.1,124.9 \pm 18.9$, and $121 \pm$ 13.2, respectively. as compared to TCN count of the CTRL (71.2 $\pm 12.1)$.

\section{Effect of ALA and cis-9, trans-11 CLA on GC Functions in vitro} Steroid Hormone Production

Concentrations of E2 and P4 were determined by RIA in the conditioned media of in vitro cultured GC treated with different concentrations of ALA and cis-9, trans-11 CLA (Figure 2). ALA significantly reduced $(P<0.05)$ the $\mathrm{E} 2$ production at all the 
TABLE 1 | Fatty acid profile of follicular fluid analyzed by Gas chromatography.

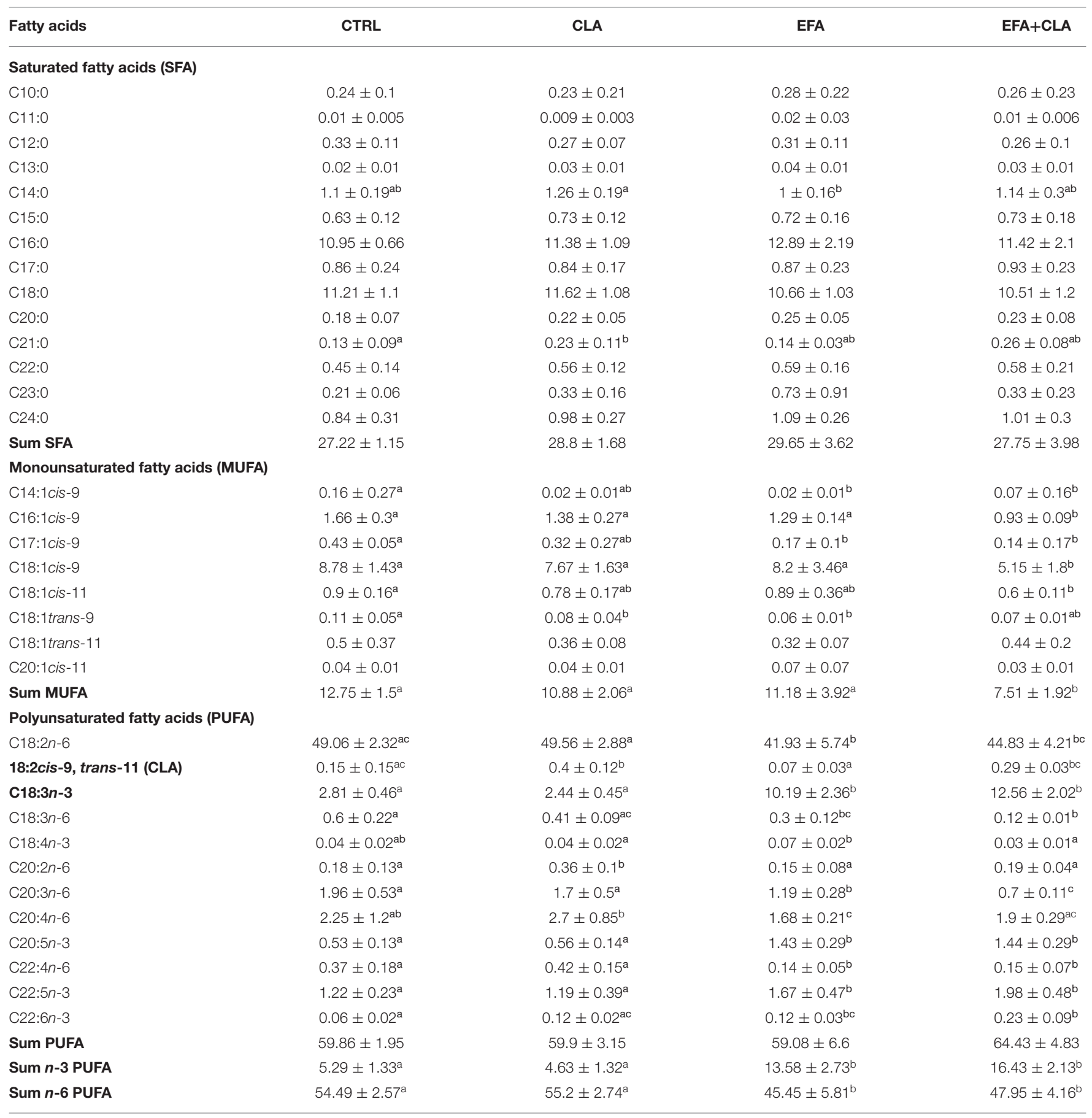

Values are \% of total fatty acids, expressed as means \pm SD. The one way ANOVA (Holm-Sidak method) or ANOVA on ranks (Dunn's Method) for pairwise multiple comparisons were used for comparing means. Values with different superscripts on the same row are significantly different $(P<0.05)$. Diet groups are CTRL: coconut oil; EFA: linseed oil + safflower oil; CLA: Lutalin $\circledast$ and EFA + CLA: linseed oil + safflower oil + Lutalin $\circledast$.

concentrations as compared to the control (Figure 2A). Cis-9, trans-11 CLA also reduced E2 significantly $(P<0.05)$ at 30 and $60 \mu \mathrm{M}$ as compared to the control (Figure 2B). P4 concentration was significantly reduced in GC treated with ALA at 20 and $40 \mu \mathrm{M}$ (Figure 2A) whereas, $\mathrm{P} 4$ was only reduced $(P<0.05)$ by cis-9, trans-11 CLA at $60 \mu \mathrm{M}$ (Figure 2B).

\section{Cell Morphology and Gene Expression}

Microscopic images taken on day 8 of in vitro culture showed that ALA and cis-9, trans-11 CLA treatment induced intracellular lipid droplet accumulation in GC in particular at higher concentrations (Figures 3A,B). Further, RT-qPCR data revealed that transcript abundance of the fatty acid translocase (CD36) 
TABLE 2 | Effects of dietary essential fatty acids on bovine in vitro embryo development.

\begin{tabular}{|c|c|c|c|c|}
\hline $\begin{array}{l}\text { Diet group } \\
\text { (No. of cows) }\end{array}$ & $\begin{array}{l}\text { No. of oocytes } \\
\text { (n) }\end{array}$ & $\begin{array}{c}\text { (\%) Cleavage rate } \\
(n)\end{array}$ & $\begin{array}{l}(\%) \text { Blastocyst } \\
\text { rate }(n)\end{array}$ & $\begin{array}{c}\text { Total cell } \\
\text { number }(n)\end{array}$ \\
\hline $\begin{array}{l}\text { CTRL } \\
(7)\end{array}$ & 61 & $\begin{array}{c}34 \pm 8.1 \\
(20)\end{array}$ & $\begin{array}{c}23.5 \pm 11.7 \\
(6)\end{array}$ & $\begin{array}{c}71.2 \pm 12.1 \\
(5)\end{array}$ \\
\hline $\begin{array}{l}\text { EFA } \\
(7)\end{array}$ & 64 & $\begin{array}{c}51.7 \pm 9.3 \\
(33)\end{array}$ & $\begin{array}{c}17.4 \pm 7.9 \\
(7)\end{array}$ & $\begin{array}{c}92.1 \pm 10.1 \\
(6)\end{array}$ \\
\hline $\begin{array}{l}\text { CLA } \\
\text { (8) }\end{array}$ & 65 & $\begin{array}{c}53.3 \pm 5.1 \\
(35)\end{array}$ & $\begin{array}{c}26.1 \pm 11.2 \\
(12)\end{array}$ & $\begin{array}{c}124.9 \pm 18.9 \\
(12)\end{array}$ \\
\hline $\begin{array}{l}\text { EFA + CLA } \\
\text { (8) }\end{array}$ & 70 & $\begin{array}{c}36.2 \pm 10.6 \\
(26)\end{array}$ & $\begin{array}{c}15.2 \pm 8.4 \\
(7)\end{array}$ & $\begin{array}{c}121 \pm 13.2 \\
(7)\end{array}$ \\
\hline
\end{tabular}

Values are means \pm SEM. CTRL: coconut oil; EFA: linseed oil + safflower oil; CLA: Lutalin ${ }^{\circledR} ; E F A+C L A$ : linseed oil + safflower oil + Lutalin ${ }^{\circledR}$
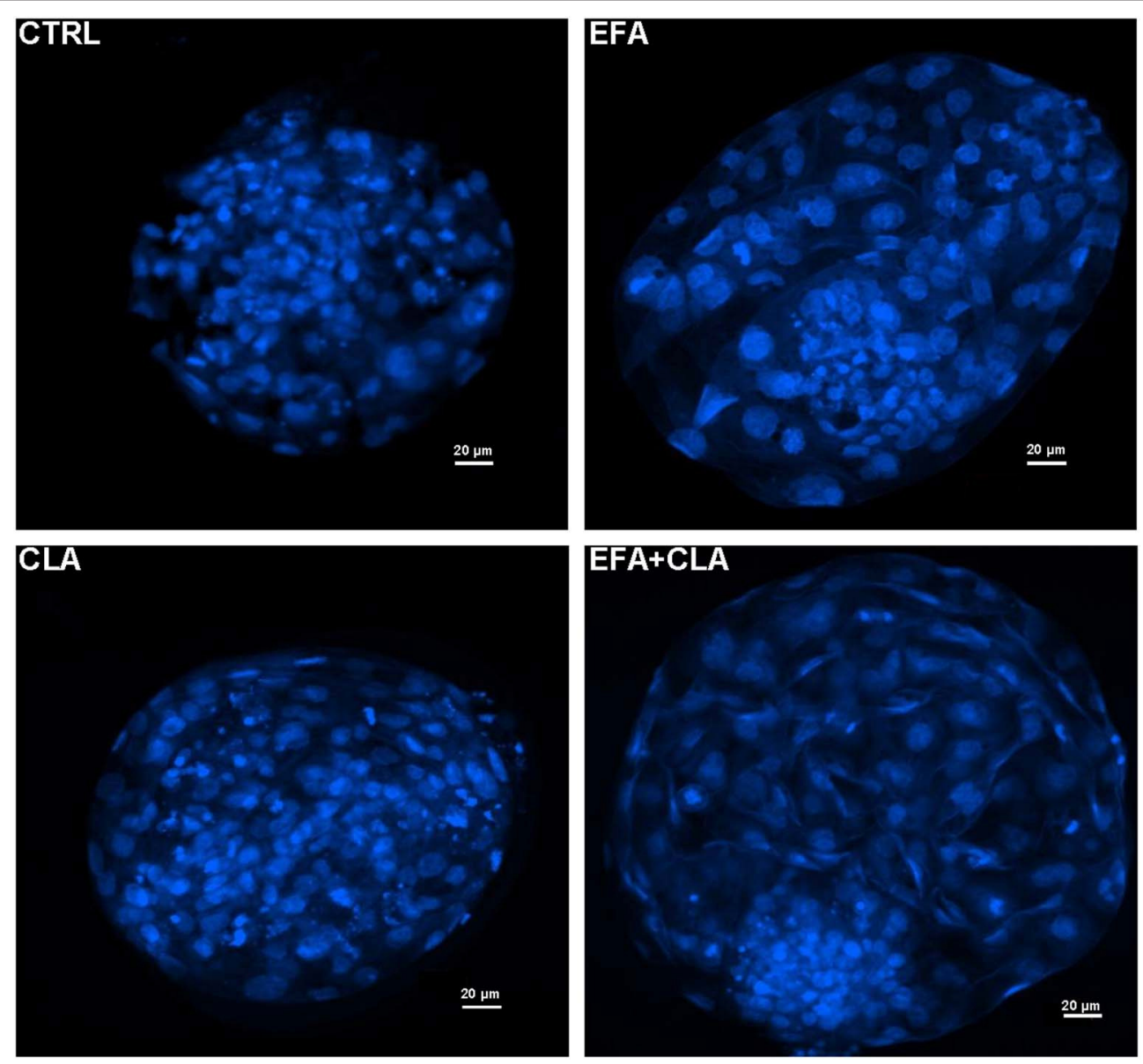

FIGURE 1 | Fluorescence images of Hoechst 33258 stained blastocyst nuclei generated from different dietary groups. CTRL: coconut oil; EFA: linseed oil + safflower oil; CLA: Lutalin ${ }^{\circledR}$; EFA + CLA: linseed oil + safflower oil + Lutalin ${ }^{\circledR}$.

was strongly up-regulated by both ALA at 40, $80 \mu \mathrm{M}$ (Figure 3C) and cis-9, trans-11 CLA at $60 \mu \mathrm{M}$ (Figure 3D). ALA in GC significantly downregulated $(P<0.05)$ the key transcripts of estradiol production, steroidogenic acute regulatory protein (STAR) at all concentrations, cytochrome P450 Family 19 subfamily A member $1(C Y P 19 A 1)$ at $(40$ and $80 \mu \mathrm{M})$, the follicle stimulating hormone receptor (FSHR) at 20 and $80 \mu \mathrm{M}$ and the luteinizing hormone/choriogonadotropin receptor (LHCGR) at $80 \mu \mathrm{M}$ (Figures 4A,B). While GC treated with cis-9, trans-11 CLA significantly downregulated $(P<0.05) S T A R$ at $60 \mu \mathrm{M}$, CYP19A1 at 30 and $60 \mu \mathrm{M}$, and both FSHR and LHCGR at $60 \mu \mathrm{M}$ (Figures 5A,B). Hydroxy-delta-5-steroid dehydrogenase, 3 beta- and steroid delta-isomerase 1 (HSD3B1) gene expression remained unaltered in ALA (Figure 4A) treated GC while it was 

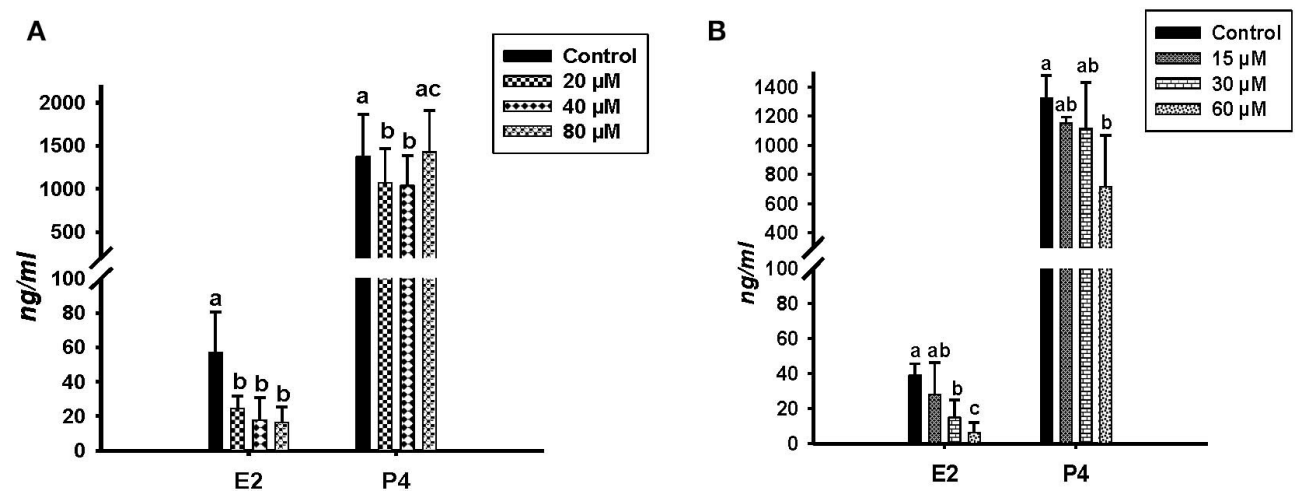

FIGURE 2 | Effects of (A) ALA (20, 40, $80 \mu \mathrm{M})(n=5)$ and (B) cis-9, trans-11 CLA (15, 30, $60 \mu \mathrm{M})(n=3)$ on 17 $\beta$-Estradiol (E2) and progesterone (P4) concentrations $(\mathrm{ng} / \mathrm{ml})$ in conditioned media of cultured GC. Data are shown as means \pm SEM; different lower case letters indicate significant differences between treatments $P<0.05)$

upregulated significantly in cis-9, trans-11 CLA $(60 \mu \mathrm{M})$ treated GC (Figure 5A). The mRNA expression of cyclin D2 (CCND2) was significantly downregulated by ALA in GC at 20 and $80 \mu \mathrm{M}$ (Figure 4C), while cis-9, trans-11 CLA downregulated CCND2 at $60 \mu \mathrm{M}(P<0.05)$ as compared to the control (Figure 5C). Proliferating cell nuclear antigen (PCNA) mRNA expression remained unaltered at all tested concentrations in both ALA and cis-9, trans-11 CLA treated GC (Figures 4C, 5C). The GC identity marker forkhead Box L2 (FOXL2) was significantly downregulated by ALA at 20 and $80 \mu \mathrm{M}$ (Figure 4D) while cis9, trans-11 CLA downregulated the same at all concentrations as compare to control (Figure 5D). In contrast, SRY-Box 9 (SOX9) gene expression was upregulated significantly (Figure 4D) in ALA treated GC but seemed slightly affected in cis-9, trans-11 CLA treated GC (Figure 5D).

\section{Cell Viability}

Flow cytometry analysis of Annexin V-FITC/PI stained cells showed no significant change in percentage of viable, apoptotic or dead cells in GC treated with different concentrations of ALA as compared to the control. Whereas, GC treated with cis-9, trans11 CLA at $60 \mu \mathrm{M}$ resulted in higher percentage of apoptotic cells $(16.3 \pm 3.1 \%)$ compared to control (10.5 $\pm 3 \%)$. Dot plots of Annexin $\mathrm{V}$ and propidium iodide (PI) staining generated during a typical flow cytometry experiment as shown in Figure 6. The percentage of dead cells in GC treated with cis-9, trans-11 CLA at 30 and $60 \mu \mathrm{M}(12.2 \pm 2.2 \%$ and $12.4 \pm 1.5 \%$, respectively) were significantly higher as compared to the control ( $8 \pm 1.6 \%)$. These results were well reflected by the percentage of viable cells going significantly down to $67.5 \pm 2.8 \%$ in GC treated with $60 \mu \mathrm{M}$ cis-9, trans-11 CLA as compare to $78.3 \pm 1.8 \%$ in the control (Table 3 ).

\section{DISCUSSION}

Dietary lipid supplementation is supposed to improve fertility in dairy cows by increasing the size of the ovulatory follicle, plasma concentration of P4 and lifespan of CL (25) though, the influence on reproductive performance is by far not fully understood. In the present study, we analyzed the effects of dietary essential fatty acids on oocyte competence and GC function in bovine.

\section{Dietary Supplementation and Embryo Development}

Following dietary supplementations, as expected we observed a higher percentage of ALA in the FF of EFA and EFA + CLA diet fed cows, while the percentage of the cis-9, trans-11 CLA was higher in the FF of CLA and EFA+CLA diet fed cows as compared to the CTRL diet fed cows. It has been reported that cows when fed with encapsulated fats containing flaxseed oil had 5-fold higher concentrations of ALA in the FF and GC with increased numbers of follicles as compare to cows fed with encapsulated fats containing sunflower oil and control diet. Also, the cleavage rates in cows fed with flax seed oil were higher than in cows fed with a control diet (26). Similarly, cows fed with flaxseed oil contained higher amounts of ALA in FF, GC, and COCs and the percentage of oocytes that developed to blastocysts was also higher in flaxseed and fish oil fed cows as compared to cows that were fed saturated fats (27). In the present study we found higher proportions of ALA and cis-9, trans-11 CLA in FF of EFA, CLA, and EFA + CLA diet group cows, however, these did not lead to significant improvements in the cleavage and blastocyst rates or TCN count. Our results revealed that neither EFA, CLA, or EFA + CLA diet supplements could improve the cleavage and blastocyst rates of in vitro generated embryos as compared to the CTRL diet supplement.

In previous studies, Holstein cows when fed with diets enriched in PUFA especially 18:2 and 18:3 FA despite improving dominant follicle size and CL volume failed to improve both cleavage and blastocyst rates of in vitro produced embryos (15). Similarly, feeding soybean oil (high in LA), or linseed oil (high in ALA) to lactating cows could not improve the blastocyst rate or TCN count of in vitro produced embryos compared to rumen inert fat (RIF) diet (28). Recent studies have provided new insights in effects of specific in vitro FA supplementation on oocyte maturation, cleavage and blastocyst rates. Supplementing cis-9, trans-11 or trans-10, cis-12 CLA 

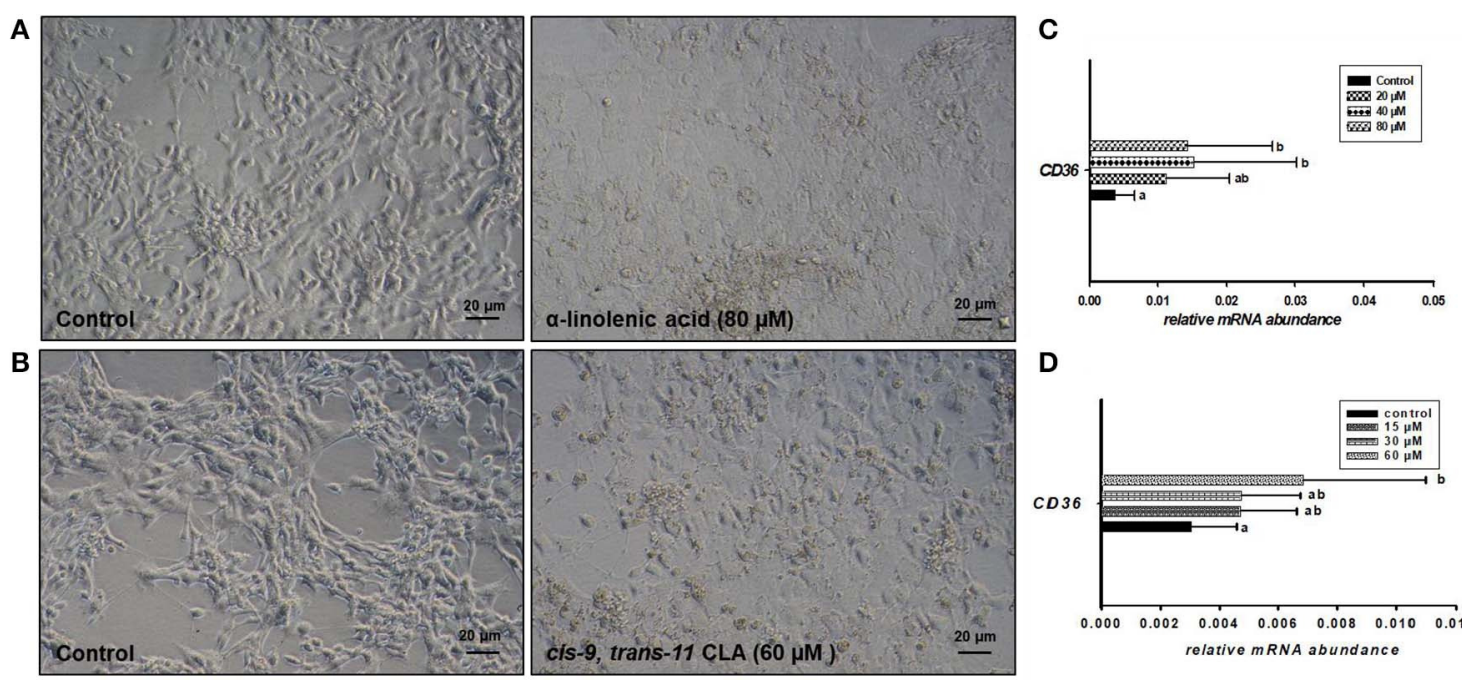

D

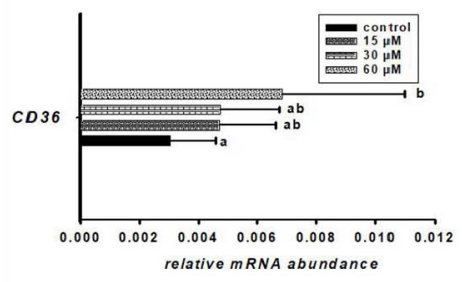

FIGURE 3 | Effects of (A) ALA $(80 \mu \mathrm{M})$ and (B) cis-9, trans-11 CLA $(60 \mu \mathrm{M})$ on the morphology of cultured GC. Photomicrographs were taken with a Nikon TMS-F inverted microscope. Effects of (C) ALA $(20,40,80 \mu \mathrm{M})(n=5)$ and (D) cis-9, trans-11CLA $(15,30,60 \mu \mathrm{M})(n=3)$ on CD36 mRNA abundance. Gene expression was normalized to $R P L P O$ transcripts. Data are shown as means $\pm \mathrm{SEM}$; different lower case letters indicate significant differences between treatments $(P<0.05)$.
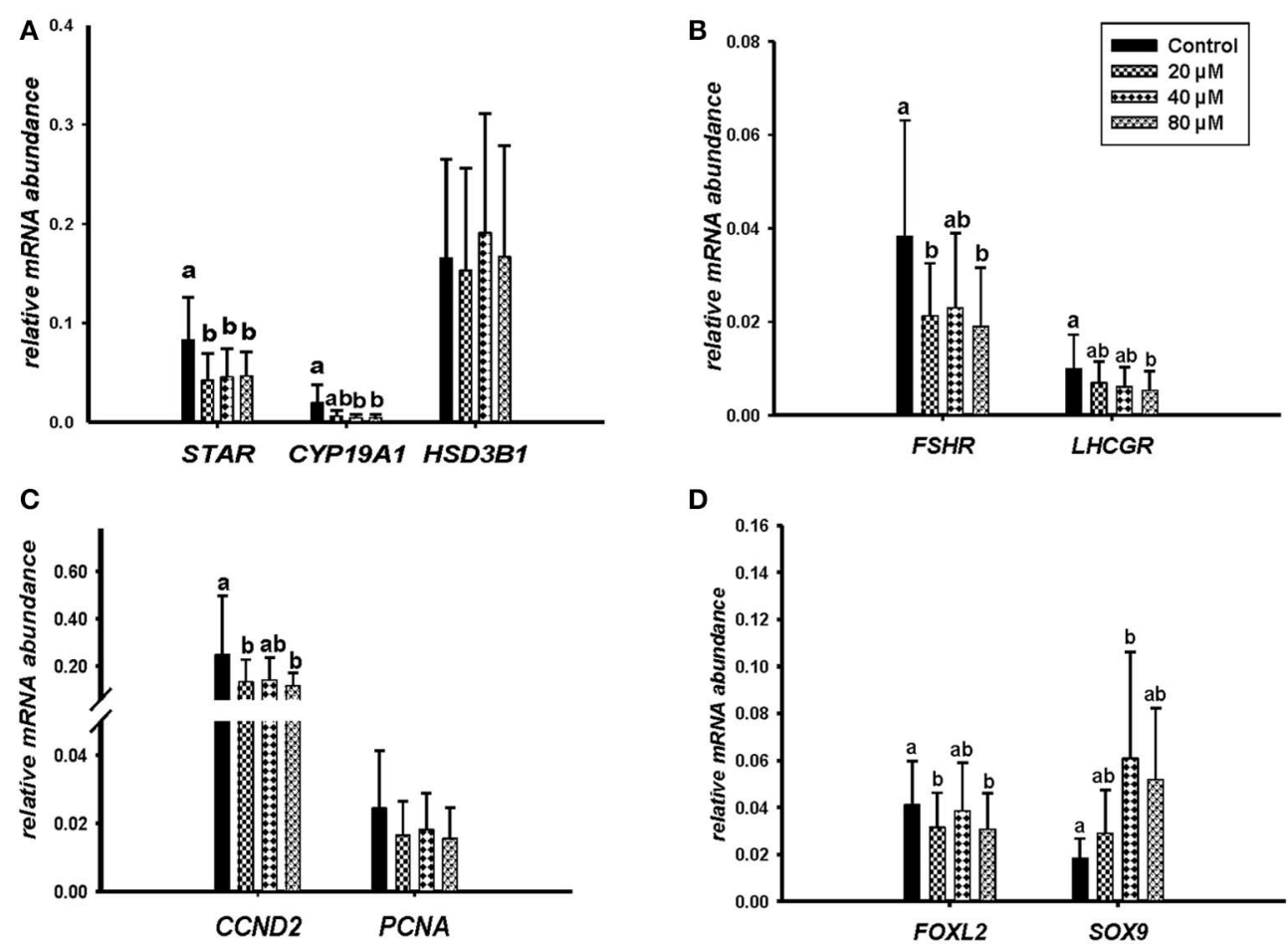

FIGURE 4 | Effects of ALA (20, 40, $80 \mu \mathrm{M})$ on the expression of (A) key genes of steroidogenesis STAR, CYP19A1, HSD3B1, (B) gonadotrophin receptors FSHR, LHCGR, (C) cell proliferation CCND2, PCNA, and (D) on GC and sertoli cell markers FOXL2, SOX9. Gene expression was normalized to RPLPO transcripts. Data are shown as means \pm SEM; different lower case letters indicate significant differences between treatments $(n=5, P<0.05)$.

isomer could not improve IVP, but embryos generated under cis9, trans-11 CLA $(100 \mu \mathrm{M})$ before vitrification were of improved quality (29). In vitro supplementation of ALA $(25 \mu \mathrm{M})$ during IVM increased the porcine oocyte cleavage rate but at higher concentration of ALA $(50 \mu \mathrm{M})$, though enhancing the nuclear maturation of oocytes it could not improve the cleavage, blastocysts rate or TCN. This suggests that high concentrations of ALA can adversely affect in vitro embryo development (30). In the present study we speculate that adverse effects of EFA and CLA diets on oocyte competence could be associated with 

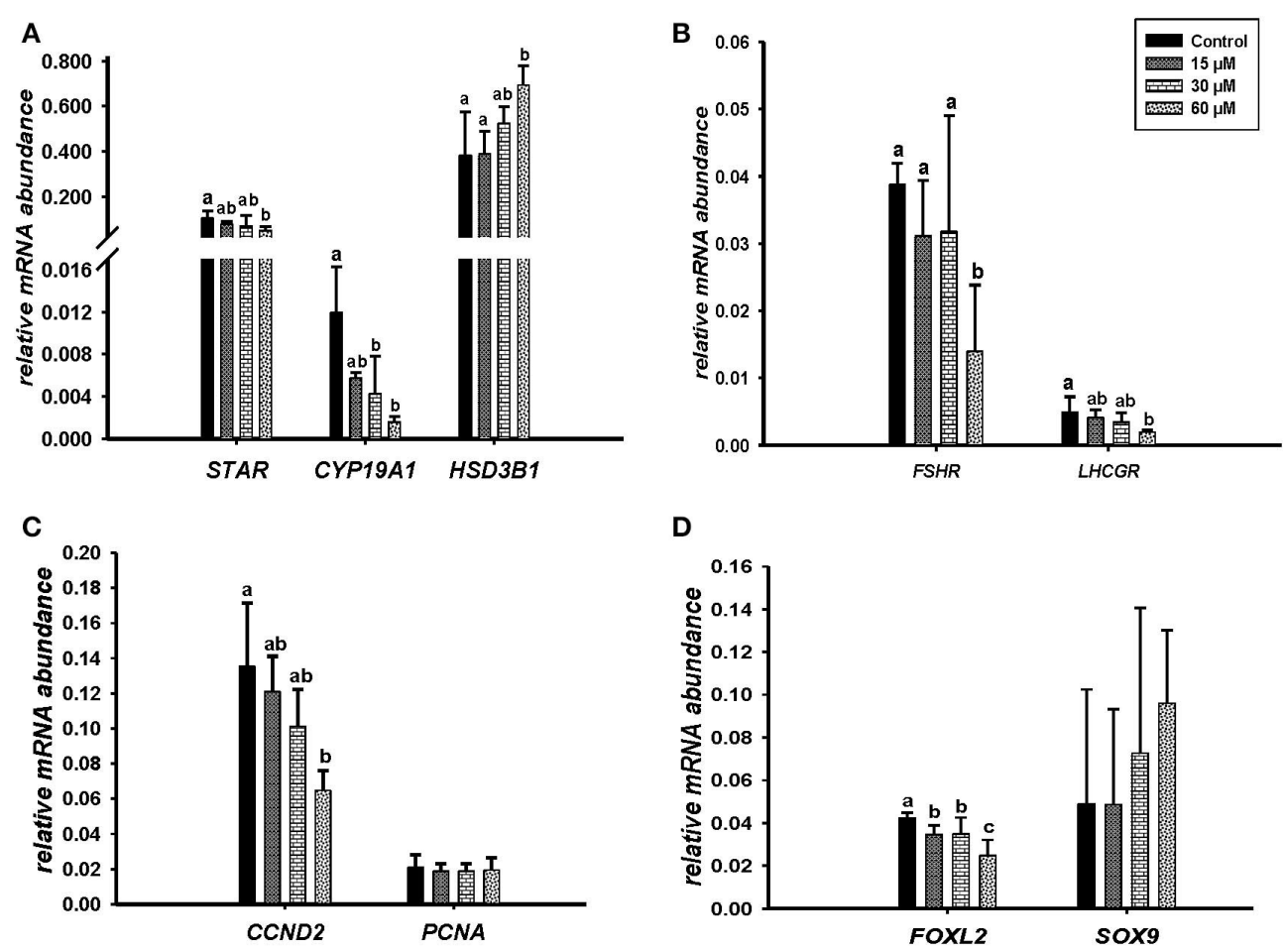

FIGURE 5 | Effects of cis-9, trans-11 CLA (15, 30, $60 \mu \mathrm{M})$ on the expression of (A) key genes of steroidogenesis STAR, CYP19A1, HSD3B1, (B) gonadotrophin receptors FSHR, LHCGR, (C) cell proliferation CCND2, PCNA, and (D) on GC and sertoli cell markers FOXL2, SOX 9. Gene expression was normalized to RPLPO transcripts. Data are shown as means \pm SEM; different lower case letters indicate significant differences between treatments $(n=3, P<0.05)$.
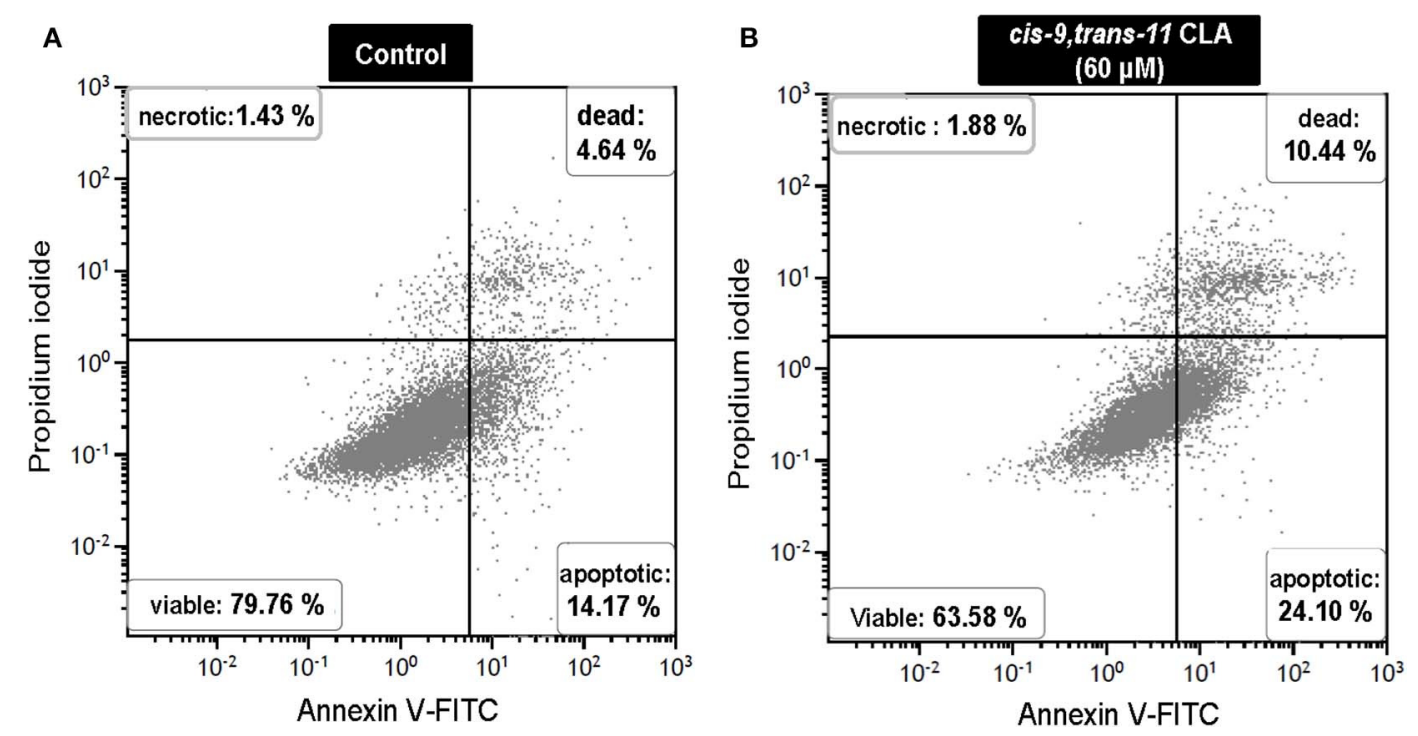

FIGURE 6 | Representative dot plots of Annexin $\mathrm{V}$ and propidium iodide (PI) staining generated during a flow cytometry experiment. Annexin $\mathrm{V}$ and PI staining in (A) control and (B) cis-9, trans-11 CLA $(60 \mu \mathrm{M})$ cultured GC. Percentage of cells stained in each quadrant is listed in the corner of each quadrant.

higher proportions of ALA and cis-9, trans-11 CLA as observed in the FF. Previous studies have documented the decisive role of FF components in determining oocyte quality and fertility in bovine and humans $(31,32)$. However, the small sample size could be a limitation in achieving decent blastocyst rates.
Another plausible reason could be the experimental approach of oocyte retrieval from subordinate follicles. Since the ovaries were obtained from cows at different oestrous stage, which might affect their oocyte development competence as dominant follicle might suppress the subordinate follicles. And thus, the sliced 
TABLE 3 | Cell viability as determined by Annexin V-FITC/PI staining assay in bovine in vitro granulosa cells.

\begin{tabular}{|c|c|c|c|c|c|c|c|c|}
\hline \multirow[b]{2}{*}{ Treatments } & \multicolumn{4}{|c|}{$\alpha$-linolenic acid (ALA) } & \multicolumn{4}{|c|}{ cis-9, trans 11 CLA } \\
\hline & control & $20 \mu \mathrm{M}$ & $40 \mu \mathrm{M}$ & $80 \mu \mathbf{M}$ & control & $15 \mu \mathrm{M}$ & $30 \mu \mathbf{M}$ & $60 \mu \mathrm{M}$ \\
\hline Viable cells (\%) & $76.4 \pm 0.5$ & $70.4 \pm 4.1$ & $66.9 \pm 2.6$ & $73.7 \pm 1.7$ & $78.3 \pm 1.8^{a}$ & $75.6 \pm 3.9^{a b}$ & $71.7 \pm 3.7^{\mathrm{ab}}$ & $67.5 \pm 2.8^{b}$ \\
\hline Apoptotic cells (\%) & $10.5 \pm 3.5$ & $10.8 \pm 1.4$ & $12.9 \pm 5.4$ & $10.6 \pm 2.9$ & $10.5 \pm 3.0^{a}$ & $9.8 \pm 2.5^{\mathrm{ab}}$ & $11.9 \pm 2.2^{\mathrm{ab}}$ & $16.3 \pm 3.1^{b}$ \\
\hline Dead cells (\%) & $9.4 \pm 2.5$ & $14.6 \pm 4.4$ & $14.1 \pm 1.8$ & $11.7 \pm 1.0$ & $8 \pm 1.6^{a}$ & $11.2 \pm 2.6^{a b}$ & $12.2 \pm 2.2^{b}$ & $12.4 \pm 1.5^{b}$ \\
\hline
\end{tabular}

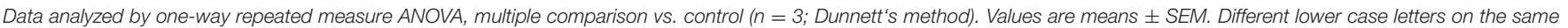
row indicate significant differences between treatments $(P<0.05)$.

follicles might not reflect the environment of the dominant preovulatory follicle. Furthermore, the selective dietary uptake of EFA and CLA supplementation leading to increased proportions of ALA and cis-9, trans-11 CLA in the follicular fluid might adversely affect developmental competence of oocytes residing within the follicles.

\section{ALA and cis-9, trans-11 CLA Alter GC Morphology and the Expression of Identity Marker Genes}

In vitro supplementation of ALA and cis-9, trans-11 CLA induced significant alterations of the morphology of cultured GC. The morphology of the cells was similar to oleid acid (OA) treated GC that we already reported earlier (33). These morphological changes are in line with the observation of an increased mRNA abundance of fatty acid translocase, CD36, which is known to mediate fatty acid uptake (34). The observed results are also consistent with reports in other mammalian cell lines. Cis-9, trans-11 CLA induced lipid accumulation in human macrophages and in mice $15 \mathrm{P}-1$ cell lines (testicular cells) along with an elevated expression of $C D 36(35,36)$. ALA enriched diets increased the transport of lipids into resting skeletal muscles in conjunction with increased sarcolemmal $\omega-3$ PUFA content and CD36 protein expression in rats (37). This suggests that both ALA and cis-9, trans-11 CLA are well-accumulated in mammalian cells either in vitro or in vivo as diet supplements.

The transcriptional regulators, FOXL2 and SOX9 are well-associated to each other (38) as FOXL2 prevents transdifferentiation of the adult ovary to testis. Inducible deletion of FOXL2 in adult ovarian follicles can upregulate the testis-specific marker gene SOX9 (39). Previously, we reported that OA markedly reduced the transcription of FOXL2 and increased SOX9 in cultured GC (40). A similar regulation was observed in the present study with ALA and cis-9, trans-11 CLA supplementation decreasing the mRNA abundance of FOXL2 and upregulating SOX 9 transcripts. Apart from being an GC identity marker FOXL2 is also known to regulate ovarian steroid metabolism (41). The presented results clearly indicate that both, ALA and cis-9, trans-11 CLA modulate the FOXL2 transcriptional activity. Thus, the role of FOXL2 in regulating the lipid metabolism in terms of promoting lipid droplet formation in GC upon ALA and cis-9, trans-11 CLA treatment could be well-anticipated from the presented data. The results suggest that both ALA and cis-9, trans-11 CLA impose alike effects on the transcript levels of FOXL2 in GC which might further affect other downstream target molecules involved in normal GC function.

\section{ALA and cis-9, trans-11 CLA Modulate GC Steroidogenesis}

For normal GC function, steroidogenesis is initiated by the transportation of free cytoplasmic cholesterol into mitochondria by the protein STAR (42). Successive steps are then catalyzed by cholesterol side chain cleavage enzyme encoded by cytochrome P450 side-chain cleavage enzyme (CYP11A1), by 3 beta hydroxyl steroid dehydrogenase transcribed from $H S D 3 B 1$, and by CYP19A1 encoding the key enzyme of E2 synthesis (43). Steroidogenesis is a vital part of folliculogenesis as studied in knockout mouse models (44). Also FSHR and LHCGR play a vital role during follicle maturation (45).

In the present study, we determined the effects of ALA and cis-9, trans-11 CLA on steroid hormone production, on transcriptional activity of key genes involved in steroidogenesis (CYP19A1, STAR, and HSD3B1) and gonadotropin hormone signaling (FSHR and LHCGR) in cultured GC. The transcript level of STAR as well as the E2 production was significantly downregulated by both ALA and cis-9, trans-11 CLA. Most likely, the reduction in E2 concentrations can be attributed to reduced transcription of CYP19A1 as observed after ALA and cis-9, trans-11 CLA treatment. CLA has been shown to be very potent in reducing CYP19A1 expression and E2 production in buffalo GC as well (46). Another PUFA, arachidonic acid (AA) at $50 \mu \mathrm{M}$ stimulates the proliferation of bovine GC by activating both extracellular signal-regulated kinases 1/2 (ERK1/2) and Akt signaling pathway, however, higher dose decreases E2 secretion and downregulates the mRNA abundance of CYP19A1, FSHR, $H S D 3 B 1$, and STAR in cultured bovine GC (47). This, suggest that PUFA at higher levels might modulate steroidogenesis by intracellular signaling pathways that regulate target gene expression. FSH is known to induce the expression of LHCGR via protein kinase $\mathrm{A}$ (PKA) and phosphoinositide3-kinase (PI3K) pathways in rat GC (48). LHCGR is highly expressed in GC during the pre-ovulatory stage to enable responsiveness to the LH surge thus leading to ovulation, oocyte maturation and CL formation (49). The down-regulation of FSHR and LHCGR by both FA at higher concentrations might affect follicle stimulating hormone (FSH) signaling and steroidogenesis in GC as suggested by our results. CYP11A1 converts cholesterol into pregnenolone and $H S D 3 B 1$ converts pregnenolone into P4 (50). HSD3B1 gene expression though remained unaltered in GC treated with ALA but $\mathrm{P} 4$ production was reduced. Similar effects on $\mathrm{P} 4$ production 
have been observed in primary goat GC treated with ALA at $100 \mu \mathrm{M}$ (51). Surprisingly, cis-9, trans-11 CLA significantly upregulated $H S D 3 B 1$ gene expression while reducing the $\mathrm{P} 4$ concentration in conditioned media. This outcome might be due to negative feedback effects of $\mathrm{P} 4$ production on $H S D 3 B 1$ transcription. Together, these results suggest that high levels of ALA or cis-9, trans-11 CLA in FF can adversely affect GC by reducing both $\mathrm{E} 2$ and $\mathrm{P} 4$ production, which in turn could result in compromised ovarian cyclicity and impaired fertility in lactating cows. This is also in line with our recent study, where we could show that increased concentrations of OA in the follicular fluid can actually impair the functionality of GC in situ, thus obviously suppressing ovulation (21).

\section{cis-9, trans-11 CLA Induces Apoptosis in GC}

It is well-documented that higher E2 levels are capable of protecting GC from Fas ligand induced apoptosis and promote the cell transit from $\mathrm{G} 1$ to $\mathrm{S}$ phase with increased CCND2 expression (52, 53). In our results, GC morphology was altered upon ALA and cis-9, trans-11 CLA treatment, and both ALA and cis-9, trans-11CLA could down-regulate CCND2 mRNA expression. However, only cis-9, trans-11CLA could elicit significant apoptotic effects in GC. As reported earlier, CLA is known to induce apoptosis in human, mouse and rat cell lines (54-57). CCND2 mRNA expression is FSH dependent as reported in FSHR null mutant mice exhibiting decreased CCND2 mRNA levels (58). This goes well in line with our observation that cis-9, trans-11 CLA treated cells not only reduced E2 production, but also reduced FSHR mRNA expression followed by a steep downregulation of CCND2 mRNA expression.

In contrast, ALA despite of reducing the E2 levels and CCND2 mRNA abundance did not induce any apoptotic effects in GC. This observation suggests the importance of FSH signaling during cell cycle regulation of GC. However, proliferating cell nuclear antigen (PCNA) gene expression remained unaltered in GC treated with both ALA and cis-9, trans-11 CLA. According to previous immunocytochemistry studies different cis-9, trans-11 CLA concentrations at different time periods could significantly decrease the PCNA expression and inhibit cell growth and proliferation in mammary cancer cells (MCF-7 cells) (59) and in gastric adenocarcinoma cell lines (SGC-7901) (60). However, these effects were only observed on translation/protein levels as changes of transcript abundance were not determined.

\section{CONCLUSION}

We investigated the effects of dietary essential fatty acids on bovine oocyte competence and GC functionality. Essential fatty

\section{REFERENCES}

1. Mattos R, Staples CR, Thatcher WW. Effects of dietary fatty acids on reproduction in ruminants. Rev Reprod. (2000) 5:38-45. doi: $10.1530 /$ ror. 0.0050038

2. Shingfield KJ, Beever DE, Reynolds CK, Gulati S, Humphries D, Lupoli B, et al. Effect of Rumen Protected Conjugated Linoleic Acid on Energy Metabolism acid supplementation could not improve the embryo IVP in spite of a substantial increase of ALA and cis-9, trans-11 CLA in the follicular fluid. Further, the study clearly suggests that GC morphology and functionality could be considerably affected with increased follicular proportions of ALA and cis9, trans-11CLA particularly constraining steroidogenesis in GC. In vivo this may result in a compromised ovarian cyclicity and impaired fertility.

\section{DATA AVAILABILITY STATEMENT}

All datasets generated for this study are included in the article/Supplementary Material.

\section{ETHICS STATEMENT}

The animal study was reviewed and approved by federal state of Mecklenburg Western-Pommerania, Germany LALLF M-V TSD 7221.3-1-038/15.

\section{AUTHOR CONTRIBUTIONS}

$\mathrm{HH}$ designed the dietary supplements for the cows. AV and VR performed the ovarian follicular fluid collection. DD and TV executed the fatty acid analysis. JS and AS executed the IVF experiments. AS, VB, and JV designed and executed the in vitro cell culture experiments. AS and JV primarily wrote the manuscript, with all co-authors making significant contribution to the final manuscript.

\section{FUNDING}

This study was financially supported by FITCOW (Geschäftszeichen: 313-06.01-28-1-79.003-15) project and funds of the Federal Ministry of Food and Agriculture (BMEL) based on a decision of the Parliament of the Federal Republic of Germany via the Federal Office for Agriculture and Food (BLE) under the innovation support programme.

\section{ACKNOWLEDGMENTS}

All authors appreciate Swanhild Rodewald, Bianka Drawert, Veronika Schreiter, Maren Anders, Christian Plinski, Bergit Jentz, and Maria Dahm for their technical support.

\section{SUPPLEMENTARY MATERIAL}

The Supplementary Material for this article can be found online at: https://www.frontiersin.org/articles/10.3389/fendo. 2020.00087/full\#supplementary-material

of Dairy Cows During Early to Mid-Lactation. American Society of Animal Science (2004).

3. Wahle KW, Rotondo D, Heys SD. Polyunsaturated fatty acids and gene expression in mammalian systems. Proc Nutr Soc. (2003) 62:349-60. doi: 10.1079/PNS2003249

4. Sturmey R, Reis A, Leese H, Mcevoy T. Role of fatty acids in energy provision during oocyte maturation and early embryo development. 
Reprod Dom Anim. (2009) 44:50-8. doi: 10.1111/j.1439-0531.2009. 01402.x

5. Ashworth CJ, Toma LM, Hunter MG. Nutritional effects on oocyte and embryo development in mammals: implications for reproductive efficiency and environmental sustainability. Philos Trans R Soc B Biol Sci. (2009) 364:3351-61. doi: 10.1098/rstb.2009.0184

6. Kim J, Kinoshita M, Ohnishi M, Fukui Y. Lipid and fatty acid analysis of fresh and frozen-thawed immature and in vitro matured bovine oocytes. Reproduction. (2001) 122:131-8. doi: 10.1530/rep.0.1220131

7. Zeron Y, Sklan D, Arav A. Effect of polyunsaturated fatty acid supplementation on biophysical parameters and chilling sensitivity of ewe oocytes. Mol Reprod Dev. (2002) 61:271-8. doi: 10.1002/mrd.1156

8. Staples C, Wiltbank M, Grummer R, Guenther J, Sartori R, Diaz F, et al. Effect of long chain fatty acids on lactation performance and reproductive tissues of Holstein cows. J Dairy Sci. (2000) 83:278.

9. Vasconcelos J, Sartori R, Oliveira H, Guenther J, Wiltbank M. Reduction in size of the ovulatory follicle reduces subsequent luteal size and pregnancy rate. Theriogenology. (2001) 56:307-14. doi: 10.1016/S0093-691X(01)00565-9

10. Ambrose D, Kastelic J, Corbett R, Pitney P, Petit H, Small J, et al. Lower pregnancy losses in lactating dairy cows fed a diet enriched in $\alpha$-linolenic acid. J Dairy Sci. (2006) 89:3066-74. doi: 10.3168/jds.S0022-0302(06)72581-4

11. Lourenço M, Ramos-Morales E, Wallace R. The role of microbes in rumen lipolysis and biohydrogenation and their manipulation. Animal. (2010) 4:1008-23. doi: 10.1017/S175173111000042X

12. Castañeda-Gutiérrez E, Benefield B, De Veth M, Santos N, Gilbert R, Butler $\mathrm{W}$, et al. Evaluation of the mechanism of action of conjugated linoleic acid isomers on reproduction in dairy cows. J Dairy Sci. (2007) 90:4253-64. doi: $10.3168 /$ jds.2007-0117

13. Von Soosten D, Meyer U, Weber E, Rehage J, Flachowsky G, Dänicke S. Effect of trans-10, cis-12 conjugated linoleic acid on performance, adipose depot weights, and liver weight in early-lactation dairy cows. J Dairy Sci. (2011) 94:2859-70. doi: 10.3168/jds.2010-3851

14. Khalil WA, Marei WF, Khalid M. Protective effects of antioxidants on linoleic acid-treated bovine oocytes during maturation and subsequent embryo development. Theriogenology. (2013) 80:161-8. doi: 10.1016/j.theriogenology.2013.04.008

15. Bilby T, Block J, Do Amaral B, Sa Filho O, Silvestre F, Hansen P, et al. Effects of dietary unsaturated fatty acids on oocyte quality and follicular development in lactating dairy cows in summer. J Dairy Sci. (2006) 89:3891903. doi: $10.3168 /$ jds.S0022-0302(06)72432-8

16. Childs S, Hennessy A, Sreenan J, Wathes D, Cheng Z, Stanton C, et al. Effect of level of dietary n-3 polyunsaturated fatty acid supplementation on systemic and tissue fatty acid concentrations and on selected reproductive variables in cattle. Theriogenology. (2008) 70:595-611. doi: 10.1016/j.theriogenology.2008.04.002

17. Haubold S, Kröger-Koch C, Starke A, Tuchscherer A, Tröscher A, Kienberger $\mathrm{H}$, et al. Effects of abomasal infusion of essential fatty acids and conjugated linoleic acid on performance and fatty acid, antioxidative, and inflammatory status in dairy cows. J. Dairy Sci. (2019) 103:972-91. doi: $10.3168 /$ jds.2019-17135

18. Dannenberger D, Nuernberg G, Nuernberg K, Will K, Schauer N, Schmicke M. Effects of diets supplemented with $n-3$ or $n-6$ PUFA on pig muscle lipid metabolites measured by non-targeted LC-MS lipidomic profiling. J Food Composit Anal. (2017) 56:47-54. doi: 10.1016/j.jfca.2016.11.015

19. Dannenberger D, Nuernberg K, Nuernberg G, Priepke A. Different dietary protein and PUFA interventions alter the fatty acid concentrations, but not the meat quality, of porcine muscle. Nutrients. (2012) 4:1237-46. doi: $10.3390 /$ nu 4091237

20. Van Der Weijden VA, Chen S, Bauersachs S, Ulbrich SE, Schoen J. Gene expression of bovine embryos developing at the air-liquid interface on oviductal epithelial cells (ALI-BOEC). Reprod Biol Endocrinol. (2017) 15:91. doi: 10.1186/s12958-017-0310-1

21. Sharma A, Baddela VS, Becker F, Dannenberger D, Viergutz T, Vanselow J. Elevated free fatty acids affect bovine granulosa cell function: a molecular cue for compromised reproduction during negative energy balance. Endocr Connect. (2019) 8:493-505. doi: 10.1530/EC-19-0011

22. Baddela VS, Sharma A, Viergutz T, Koczan D, Vanselow J. Low oxygen levels induce early luteinization associated changes in bovine granulosa cells. Front Physiol. (2018) 9:1066. doi: 10.3389/fphys.2018. 01066

23. Baufeld A, Vanselow J. Increasing cell plating density mimics an early post-LH stage in cultured bovine granulosa cells. Cell Tissue Res. (2013) 354:869-80. doi: 10.1007/s00441-013-1712-9

24. Baufeld A, Vanselow J. Lactate promotes specific differentiation in bovine granulosa cells depending on lactate uptake thus mimicking an early post-LH stage. Reprod Biol Endocrinol. (2018) 16:15. doi: 10.1186/s12958-018-0332-3

25. Staples $C$, Burke J, Thatcher W. Influence of supplemental fats on reproductive tissues and performance of lactating cows. J Dairy Sci. (1998) 81:856-71. doi: 10.3168/jds.S0022-0302(98)75644-9

26. Zachut M, Dekel I, Lehrer H, Arieli A, Arav A, Livshitz L, et al. Effects of dietary fats differing in $n-6: n-3$ ratio fed to high-yielding dairy cows on fatty acid composition of ovarian compartments, follicular status, and oocyte quality. J Dairy Sci. (2010) 93:529-45. doi: 10.3168/jds.2009-2167

27. Moallem U, Shafran A, Zachut M, Dekel I, Portnick Y, Arieli A. Dietary $\alpha$-linolenic acid from flaxseed oil improved folliculogenesis and IVF performance in dairy cows, similar to eicosapentaenoic and docosahexaenoic acids from fish oil. Reproduction. (2013) 146:603-14. doi: 10.1530/REP-13-0244

28. Fouladi-Nashta AA, Wonnacott KE, Gutierrez CG, Gong JG, Sinclair KD, Garnsworthy PC, et al. Oocyte quality in lactating dairy cows fed on high levels of n-3 and n-6 fatty acids. Reproduction. (2009) 138:771-81. doi: 10.1530/REP-08-0391

29. Absalón-Medina V, Bedford-Guaus S, Gilbert R, Siqueira L, Esposito G, Schneider A, et al. The effects of conjugated linoleic acid isomers cis-9, trans-11 and trans-10, cis-12 on in vitro bovine embryo production and cryopreservation. J Dairy Sci. (2014) 97:6164-76. doi: 10.3168/jds.2013-7719

30. Lee J-E, Yong H, Kim H-Y, Lee W-H, Cheong H-T, Yang B-K, et al. Effect of alpha-linolenic acid on oocyte maturation and embryo development in pigs. Dev Reprod. (2017) 21:205. doi: 10.12717/DR.2017.21.2.205

31. Sinclair K, Lunn L, Kwong W, Wonnacott K, Linforth R, Craigon J. Amino acid and fatty acid composition of follicular fluid as predictors of in-vitro embryo development. Reprod Biomed Online. (2008) 16:859-68. doi: 10.1016/S1472-6483(10)60153-8

32. Shaaker M, Rahimipour A, Nouri M, Khanaki K, Darabi M, Farzadi L, et al. Fatty acid composition of human follicular fluid phospholipids and fertilization rate in assisted reproductive techniques. Iran Biomed J. (2012) 16:162-8. doi: 10.6091/ibj.1081.2012

33. Yenuganti VR, Viergutz T, Vanselow J. Oleic acid induces specific alterations in the morphology, gene expression and steroid hormone production of cultured bovine granulosa cells. Gen Comp Endocrinol. (2016) 232:134-44. doi: 10.1016/j.ygcen.2016.04.020

34. Su X, Abumrad NA. Cellular fatty acid uptake: a pathway under construction. Trends Endocrinol Metab. (2009) 20:72-7. doi: 10.1016/j.tem.2008.11.001

35. Stachowska E, Baskiewicz M, Marchlewicz M, Mariusz Kaczmarczyk KC, Wiszniewska B, Machalinski B, et al. Conjugated linoleic acids regulate triacylglycerol and cholesterol concentrations in macrophages/foam cells by the modulation of CD36 expression. Acta Biochim Pol. (2010) 57:379. doi: 10.18388/abp.2010_2420

36. Gillot I, Jehl-Pietri C, Gounon P, Luquet S, Rassoulzadegan M, Grimaldi P, et al. Germ cells and fatty acids induce translocation of CD36 scavenger receptor to the plasma membrane of Sertoli cells. J Cell Sci. (2005) 118:302735. doi: $10.1242 /$ jcs. 02430

37. Chorner Z, Barbeau P-A, Castellani L, Wright DC, Chabowski A, Holloway GP. Dietary $\alpha$-linolenic acid supplementation alters skeletal muscle plasma membrane lipid composition, sarcolemmal FAT/CD36 abundance, and palmitate transport rates. Am J Physiol Regul. Integr Comp Physiol. (2016) 311:R1234-42. doi: 10.1152/ajpregu.00346.2016

38. Veitia RA. FOXL2 versus SOX9: a lifelong "battle of the sexes". Bioessays. (2010) 32:375-80. doi: 10.1002/bies.200900193

39. Uhlenhaut NH, Jakob S, Anlag K, Eisenberger T, Sekido R, Kress J, et al. Somatic sex reprogramming of adult ovaries to testes by FOXL2 ablation. Cell. (2009) 139:1130-42. doi: 10.1016/j.cell.2009.11.021

40. Yenuganti VR, Vanselow J. Oleic acid induces down-regulation of the granulosa cell identity marker FOXL2, and up-regulation of the Sertoli cell marker SOX9 in bovine granulosa cells. Reprod Biol Endocrinol. (2017) 15:57. doi: $10.1186 / \mathrm{s} 12958-017-0276-\mathrm{z}$ 
41. Pisarska MD, Bae J, Klein C, Hsueh AJ. Forkhead 12 is expressed in the ovary and represses the promoter activity of the steroidogenic acute regulatory gene. Endocrinology. (2004) 145:3424-33. doi: 10.1210/en.2003-1141

42. Christenson LK, Strauss JF. Steroidogenic acute regulatory protein (StAR) and the intramitochondrial translocation of cholesterol. Biochim Biophys Acta. (2000) 1529:175-87. doi: 10.1016/S1388-1981(00)00147-5

43. Ke F-C, Chuang L-C, Lee M-T, Chen YJ, Lin S-W, Wang PS, et al. The modulatory role of transforming growth factor $\beta 1$ and androstenedione on follicle-stimulating hormone-induced gelatinase secretion and steroidogenesis in rat granulosa cells. Biol Reprod. (2004) 70:1292-8. doi: 10.1095/biolreprod.103.023531

44. Fisher CR, Graves KH, Parlow AF, Simpson ER. Characterization of mice deficient in aromatase (ArKO) because of targeted disruption of the cyp19 gene. Proc Natl Acad Sci USA. (1998) 95:6965-70. doi: 10.1073/pnas.95.12.6965

45. Ulloa-Aguirre A, Zariñán T, Jardón-Valadez E, Gutiérrez-Sagal R, Dias JA. Structure-function relationships of the follicle-stimulating hormone receptor. Front Endocrinol. (2018) 9:707. doi: 10.3389/fendo.2018.00707

46. Sharma I, Singh D. Conjugated linoleic acids attenuate FSH-and IGF1stimulated cell proliferation; IGF1, GATA4, and aromatase expression; and estradiol-17 $\beta$ production in buffalo granulosa cells involving PPAR $\gamma$, PTEN, and PI3K/Akt. Reproduction. (2012) 144:373-83. doi: 10.1530/REP-12-0079

47. Zhang N, Wang L, Luo G, Tang X, Ma L, Zheng Y, et al. Arachidonic acid regulation of intracellular signaling pathways and target gene expression in bovine ovarian granulosa cells. Animals. (2019) 9:374. doi: 10.3390/ani9060374

48. Law NC, Weck J, Kyriss B, Nilson JH, Hunzicker-Dunn M. Lhcgr expression in granulosa cells: roles for PKA-phosphorylated $\beta$-catenin, TCF3, and FOXO1. Mol Endocrinol. (2013) 27:1295-310. doi: 10.1210/me.2013-1025

49. Zhang F-P, Poutanen M, Wilbertz J, Huhtaniemi I. Normal prenatal but arrested postnatal sexual development of luteinizing hormone receptor knockout (LuRKO) mice. Mol Endocrinol. (2001) 15:172-83. doi: 10.1210/mend.15.1.0582

50. Juengel J, Niswender G. Molecular regulation of luteal progesterone synthesis in domestic ruminants. J Reprod Fertil Suppl. (1999) 54:193-205.

51. Coyral-Castel S, Rame C, Fatet A, Dupont J. Effects of unsaturated fatty acids on progesterone secretion and selected protein kinases in goat granulosa cells. Domest Anim Endocrinol. (2010) 38:272-83. doi: 10.1016/j.domaniend.2009.12.002

52. Quirk SM, Cowan RG, Harman RM. The susceptibility of granulosa cells to apoptosis is influenced by oestradiol and the cell cycle. J Endocrinol. (2006) 189:441-53. doi: 10.1677/joe.1.06549
53. Couse JF, Yates MM, Deroo BJ, Korach KS. Estrogen receptor- $\beta$ is critical to granulosa cell differentiation and the ovulatory response to gonadotropins. Endocrinology. (2005) 146:3247-62. doi: 10.1210/en.2005-0213

54. Wang L-S, Huang Y-W, Liu S, Yan P, Lin YC. Conjugated linoleic acid induces apoptosis through estrogen receptor alpha in human breast tissue. BMC Cancer. (2008) 8:208. doi: 10.1186/1471-2407-8-208

55. Miglietta A, Bozzo F, Bocca C, Gabriel L, Trombetta A, Belotti S, et al. Conjugated linoleic acid induces apoptosis in MDA-MB-231 breast cancer cells through ERK/MAPK signalling and mitochondrial pathway. Cancer Lett. (2006) 234:149-57. doi: 10.1016/j.canlet.2005.03.029

56. Park HS, Ryu JH, Ha YL, Park JH. Dietary conjugated linoleic acid (CLA) induces apoptosis of colonic mucosa in 1,2-dimethylhydrazine-treated rats: a possible mechanism of the anticarcinogenic effect by CLA. Br J Nutr. (2001) 86:549-55. doi: 10.1079/BJN2001445

57. Ou L, Ip C, Lisafeld B, Ip MM. Conjugated linoleic acid induces apoptosis of murine mammary tumor cells via Bcl-2 loss. Biochem Biophys Res Commun. (2007) 356:1044-9. doi: 10.1016/j.bbrc.2007.03.096

58. Dierich A, Sairam MR, Monaco L, Fimia GM, Gansmuller A, Lemeur M, et al. Impairing follicle-stimulating hormone (FSH) signaling in vivo: targeted disruption of the FSH receptor leads to aberrant gametogenesis and hormonal imbalance. Proceedings of the National Academy of Sciences. (1998) 95:136127. doi: 10.1073/pnas.95.23.13612

59. Liu J-R, Chen B-Q, Han X-H, Yang Y-M, Zheng Y-M, Liu R-H. Effect of cis-9, trans-11-conjugated linoleic acid on cell cycle of mammary adenocarcinoma cells (MCF-7). Chin J Cancer Res. (2002) 14:93. doi: 10.1007/s11670-002-0021-8

60. Liu J-R, Li B-X, Chen B-Q, Han X-H, Xue Y-B, Yang Y-M, et al. Effect of cis-9, trans-11-conjugated linoleic acid on cell cycle of gastric adenocarcinoma cell line (SGC-7901). World J Gastroenterol. (2002) 8:224. doi: $10.3748 /$ wjg.v8.i2.224

Conflict of Interest: The authors declare that the research was conducted in the absence of any commercial or financial relationships that could be construed as a potential conflict of interest.

Copyright (C) 2020 Sharma, Baddela, Roettgen, Vernunft, Viergutz, Dannenberger, Hammon, Schoen and Vanselow. This is an open-access article distributed under the terms of the Creative Commons Attribution License (CC BY). The use, distribution or reproduction in other forums is permitted, provided the original author(s) and the copyright owner(s) are credited and that the original publication in this journal is cited, in accordance with accepted academic practice. No use, distribution or reproduction is permitted which does not comply with these terms. 